\title{
Flucloxacillin in bone
}

\author{
P. F. UNSWORTH, ${ }^{1}$ F. W. HEATLEY, AND I. PHILliPS \\ From the Departments of Microbiology and Orthopaedic Surgery, St Thomas' Hospital, London, UK
}

SUMMARY Ten patients undergoing total hip replacement for osteoarthritis were each given intramuscular flucloxacillin about two hours preoperatively; bone and serum were sampled simultaneously at operation. Trabecular and compact bone were separated, partly dried, reduced to powders, and then extracted with buffer. The concentration of flucloxacillin in bone washings and serum was determined by well-diffusion assay. The mean concentration of flucloxacillin in serum was $8.9 \mathrm{mg} / \mathrm{l}$, in trabecular bone washings, $1.3 \mathrm{mg} / \mathrm{l}$, and in compact bone washings $0.9 \mathrm{mg} / 1$. The amount of blood contaminating the bone washings was measured, and was calculated to account for at most $26 \%$ of the flucloxacillin present. The significance of these findings is discussed in relation to the prophylactic use of flucloxacillin in hip replacement surgery.

Although deep infection rates after total hip replacement operations are of the order of only 2 to $6 \%$ (Benson and Hughes, 1975) deep infection is a serious complication as it usually necessitates removal of the prosthesis.

The commonest organisms causing deep infection are coagulase-positive and -negative staphylococci (Visuri et al., 1976), and a number of studies have been made with various prophylactic antibiotics (Ericson et al., 1973; Parsons, 1976). Lincomycin and clindamycin have the drawback of causing pseudomembraneous colitis in some patients, and fucidin, when used alone, may cause resistant organisms to emerge (Garrod et al., 1973a). The cephalosporins and gentamicin are broad-spectrum antibiotics, and gentamicin must be injected and is toxic at high concentrations. The penicillinase-resistant penicillins are active against most staphylococci, have a narrow spectrum of antibacterial activity, and are safe.

Some of the penicillinase-resistant penicillins have been studied in hip replacement surgery, and concentrations of oxacillin (Kolczun et al., 1974) and methicillin (Schurman et al., 1975) in bone have been measured. Little work, however, has been done on flucloxacillin; in the present investigation we measured bone concentrations of flucloxacillin and attempted to determine whether antibiotic found in bone was due to blood contamination.

${ }^{1}$ Present address: Cross-Infection Reference Laboratory, Central Public Health Laboratory, Colindale Avenue, London NW9 5HT.

Received for publication 22 December 1977

\section{Material and methods}

\section{PATIENTS}

The 10 patients studied were about to undergo Müller total hip replacement for osteoarthritis. A dose of 0.5 or $1 \mathrm{~g}$ of flucloxacillin was given intramuscularly along with the anaesthetic premedication, and the time was noted. The weights of seven of the patients were recorded and their weight-related doses were calculated.

SAMPLING AND STORAGE OF SERUM, MARROW, AND BLOOD

Venous blood was withdrawn within a few minutes of removal of the femoral head, and the time was noted. Serum was separated and assayed for flucloxacillin content with minimal delay; storage time and temperature were recorded. The venous blood haemoglobin concentration and haematocrit were measured by Coulter counter.

Specimens of marrow were aspirated from four femoral shafts after removal of the heads, and the time of aspiration was recorded for two. Aspirates from patients 4 and 9 were allowed to stand, and the supernatants were assayed for flucloxacillin; the whole aspirates from cases 1 and 10 were assayed.

Packed erythrocytes of patient 7 were separated and assayed for flucloxacillin whole and after lysis by addition of a drop of saponin $2 \% \mathrm{w} / \mathrm{v}$.

PREPARATION OF BONE WASHINGS

The femoral head and attached part of the femoral neck was excised and the time was noted in each case. Delay was minimised and the storage time and temperature were recorded. 
Excess surface blood was wiped off with tissue paper. A band saw was used to cut the bone, thus removing the entire surface layer, separating trabecular bone from a plate of compact bone in the upper aspect of the femoral neck, and reducing the bone to pieces of about $1 \mathrm{~cm}^{3}$. These were further reduced with pliers to about $3 \mathrm{~mm}^{3}$. Relatively sclerotic ('hard') and more normal ('soft') parts of the trabecular bone of patient 10 were treated separately. Cysts in bone were not sampled.

Bone fragments were exposed overnight to dried silica gel at $5^{\circ} \mathrm{C}$ and $-70 \mathrm{~cm}$ mercury to render them more brittle; the reduction in weight was measured for one bone. Next the fragments were pulverised in a mortar and pestle, with paper between the mortar and the fragments of compact bone to prevent richochets. The size of bone particles after pestling was roughly measured by ruler. Phosphate buffer, $\mathrm{pH} 7$, was added to the ground bone, $1 \mathrm{ml} / \mathrm{g}$ of bone. The suspension was shaken for 38-70 (mean 54) min at $5^{\circ} \mathrm{C}$ and then centrifuged at $2000 \mathrm{rpm}$ for $10 \mathrm{~min}$ through a $13 \mathrm{~mm}$ antibiotic assay disc (Whatman Ltd) in a 5-ml syringe barrel (Gillette Surgical Ltd). The bone washings obtained were assayed for flucloxacillin concentration; protein and haemoglobin concentrations were measured (see below). The bone processing was based on a method of D. S. Reeves and his colleagues (personal communication).

Washings from patients 1,9 , and 10 were further filtered through a $0.2 \mu \mathrm{m}$ membrane (Millipore Ltd) before being used for haemoglobin estimation. Washings from patient 10 were tested for the estimation of haemoglobin and flucloxacillin before and after membrane filtration.

HAEMOGLOBIN IN BONE WASHINGS

To assess contamination with blood, the haemoglobin concentration in bone washings from three patients was determined by measuring the maximum height of the peak of absorbance in the Soret band (400-420 nm) using an SP800A scanning spectrophotometer (Unicam Ltd). A control sequestrene specimen of normal venous blood of known haemoglobin concentration was treated as were the bones: that is, it was frozen at $-20^{\circ} \mathrm{C}$ for $2 \mathrm{~h}$, partially dried over silica gel, and shaken with $1 \mathrm{ml} / \mathrm{g}$ of buffer; doubling dilutions in buffer were made up to $1 / 10240$ $(0.01 \%, v / v)$. The maximum absorbance in the Soret band was measured for each dilution and plotted against haemoglobin concentration. This graph was used to convert maximum absorbances to concentrations of blood in the bone washings. To correct for any differences in haemoglobin concentration of the control blood and the patient's blood, the concentration of blood in the bone washings was multiplied by the ratio of the haemoglobin concentrations of the control blood and the patient's blood.

Protein in the bone washings of two patients was measured by means of Albustix (Ames Ltd) and by precipitation with $3 \%$ sulphosalicylic acid.

\section{ASSAY METHOD}

Concentrations of flucloxacillin in serum, marrow samples, erythrocytes, and bone washings were assayed by well diffusion. The medium used was Diagnostic Sensitivity Agar (Oxoid Ltd) and the test organism a clinical isolate of Staphylococcus aureus sensitive to methicillin. Plates were flooded with a $1 / 100$ dilution of overnight broth culture and then drained for $3 \mathrm{~min}$ to yield semiconfluent growth. Standard solutions of flucloxacillin in phosphate buffer, $\mathrm{pH} \mathrm{7,} \mathrm{were} \mathrm{used} \mathrm{to} \mathrm{assay} \mathrm{bone} \mathrm{washings,} \mathrm{and}$ standards were made up in horse serum to assay sera, marrow specimens, and erythrocytes. We compared flucloxacillin standards made up in phosphate buffer, $\mathrm{pH} 7$, with and without the addition of horse serum, $1 \mathrm{~g} / \mathrm{l}$, which was equivalent to the concentration of protein found in bone washings. A control of flucloxacillin, $5 \mathrm{mg} / 1$, was made separately from the standards. Standards and controls were stored in liquid nitrogen $\left(-198^{\circ} \mathrm{C}\right)$ and compared with fresh standards after storage. Assay plates were kept at $5^{\circ} \mathrm{C}$ for $2 \mathrm{~h}$ to allow prediffusion and then incubated at $37^{\circ} \mathrm{C}$ for $18 \mathrm{~h}$.

AMOUNT OF ANTIBIOTIC IN BONE WASHINGS ATTRIBUTABLE TO CONTAMINATION WITH BLOOD

The amount ( $c \mathrm{mg} / \mathrm{l}$ ) of flucloxacillin in bone washings due to contamination with blood was calculated from the formula:

$$
c=\frac{b}{100} \times \frac{(100-h)}{100} \times \mathrm{s}
$$

where $b$ is the concentration of blood in the bone washings $(\%), h$ the patient's blood haematocrit $(\%)$, and $s$ the concentration $(\mathrm{mg} / \mathrm{l})$ of flucloxacillin in the patient's serum.

\section{Results}

PATIENTS' AGES, SEX, AND DRUG DOSAGES These are shown in Table 1. Ages ranged from 61 to 87 (mean 69.4) years. There were five men and five women. The weight-related doses of flucloxacillin for seven patients ranged from 6.4 to 15.9 (mean $10.4) \mathrm{mg} / \mathrm{kg}$. The dose given to each is shown.

DOSE SAMPLING INTERVAL

The mean intervals between giving the injection of 
Table 1 Patients' data and dosage

\begin{tabular}{llllll}
\hline Patient & $\begin{array}{l}\text { Age } \\
(y r)\end{array}$ & $\begin{array}{l}\text { Sex } \\
(M / F)\end{array}$ & $\begin{array}{l}\text { Weight } \\
(\mathrm{kg})\end{array}$ & \multicolumn{2}{c}{ Dose of flucloxacillin } \\
\cline { 5 - 6 } & & & & $(\mathrm{g})$ & $(\mathrm{mg} / \mathrm{kg})$ \\
\hline 1 & 69 & M & 75 & $0 \cdot 5$ & $6 \cdot 7$ \\
2 & 69 & F & 76 & $0 \cdot 5$ & $6 \cdot 6$ \\
3 & 66 & M & 80 & $1 \cdot 0$ & $12 \cdot 5$ \\
4 & 66 & M & 78 & $0 \cdot 5$ & $6 \cdot 4$ \\
5 & 74 & M & - & $1 \cdot 0$ & - \\
6 & 61 & F & - & $0 \cdot 5$ & - \\
7 & 70 & F & - & $0 \cdot 5$ & - \\
8 & 87 & F & $45 *$ & $0 \cdot 5$ & $11 \cdot 1$ \\
9 & 70 & F & 63 & $1 \cdot 0$ & $15 \cdot 9$ \\
10 & 62 & M & 73 & 1.0 & $13 \cdot 7$ \\
\hline
\end{tabular}

*Approximate weight.

flucloxacillin and sampling bone and serum were $2 \mathrm{~h} 12 \mathrm{~min}$ and $2 \mathrm{~h} 13 \mathrm{~min}$ (ranges $1 \mathrm{~h} 45 \mathrm{~min}$ and $1 \mathrm{~h} 51 \mathrm{~min}-3 \mathrm{~h} 20 \mathrm{~min}$ ) respectively. The maximum delay between sampling bone and serum in any patient was $15 \mathrm{~min}$ and the mean delay was $4.8 \mathrm{~min}$. Marrow aspirates were taken from patients $1,4,9$, and 10 within about two to three hours of the injection of flucloxacillin.

\section{STORAGE OF SAMPLES}

Sera and bones were exposed to room temperature $\left(c 20^{\circ} \mathrm{C}\right)$ for a mean of $3.5 \mathrm{~h}$ and a maximum of 9 and $12 \mathrm{~h}$ respectively, to $5^{\circ} \mathrm{C}$ for up to $18 \mathrm{~h}$ and to $-20^{\circ} \mathrm{C}$ for up to 10 days (mean $2 \cdot 3$ and 1.2 days). The ranges and means are thus similar for sera and bones. Marrow and erythrocyte specimens were stored for up to a few days at $5^{\circ} \mathrm{C}$.

\section{CHARACTER OF THE PROCESSED BONE}

Grinding of bone by mortar and pestle resulted in a fine bone-particle size of approximately $0.1 \mathrm{~mm}$ or less. Trabecular bone was reduced to a wet paste and compact bone to a damp powder (Fig. 1). The trabecular bone of patient 6 was unusually soft and degenerate. That of patient 10 was especially sclerotic in parts. On exposure to silica gel, the trabecular bone from patient 8 was reduced in weight by $17 \%$, and compact bone by $15 \%$. The protein content of bone washings from two patients was found to be about $1 \mathrm{~g} / \mathrm{l}$.

\section{CONTAMINATION WITH BLOOD}

Table 3 shows the maximum absorbance in the Soret band for each sample of bone washings examined. In all cases the absorption peak was symmetrical, and maximum absorption occurred between 404 and $409 \mathrm{~nm}$. The control normal blood specimen contained haemoglobin $13.7 \mathrm{~g} / \mathrm{dl}$. Dilutions of this blood in buffer gave similar symmetrical absorption peaks, with maxima between 405 and $407 \mathrm{~nm}$. The maximum absorption was directly proportional to the concentration of haemoglobin. The slope of the line obtained by plotting concentration ( $v / v)$ of blood ( $\%$ ) against maximum absorbance (units) was $0 \cdot 176$, and multiplication by this factor converts maximum absorbance to concentration of blood in the washings. The haemoglobin concentrations of the patients, as shown in Table 3, were close to $13.7 \mathrm{~g} / \mathrm{dl}$. The corrected concentration of blood in the washings is shown. In none of the bone washings was this more than $2.6 \%$. In the case of patient 10 , soft and hard trabecular bone was tested separately, and the concentration of haemoglobin was higher in washings of the softer bone. Washings of compact bone in most cases contained less blood than trabecular bone washings from the same patient. After filtration through a $0.2 \mu \mathrm{m}$ membrane the maximum absorbance of the washings of hard trabecular bone of patient 10 was unchanged by more than $\pm 10 \%$.

\section{FLUCLOXACILLIN STANDARDS}

The accuracy of the flucloxacillin standards was such that the $5 \mathrm{mg} / \mathrm{l}$ control varied from the expected value by a maximum of $\pm 20 \%$. Control solutions of flucloxacillin continued to meet this criterion after storage at $-198^{\circ} \mathrm{C}$ for 30 days or at $-20^{\circ} \mathrm{C}$ for five days. Standards made up in phosphate buffer with and without the addition of $1 \mathrm{~g} / \mathrm{l}$ of serum gave zones of equal diameter. The lower limits of detection of flucloxacillin in buffer and in serum were 0.3 and $0.8 \mathrm{mg} / 1$ respectively. Fine growth occurred within the zone around standards and test fluids containing $3.1 \mathrm{mg} / 1$ or less of flucloxacillin, with more growth the lower the concentration. Standards and tests were identical in this.

\section{FLUCLOXACILLIN ASSAYS}

The sera contained 4.6-17.0 (mean 8.9) mg flucloxacillin per 1 (Table 2 ). Washings of trabecular bone contained flucloxacillin $0 \cdot 3-2 \cdot 2$ (mean $1 \cdot 3$ ) $\mathrm{mg} / \mathrm{l}$, that is, $5 \cdot 9-26.4$ (mean $15 \cdot 6$ ) $\%$ of the corresponding serum concentrations. Nine of the washings of compact bone contained flucloxacillin 0.3-2.0 (mean 0.9) $\mathrm{mg} / \mathrm{l}$, that is, $5 \cdot 2-22.6$ (mean $11 \cdot 6$ ) $\%$ of the corresponding serum concentrations. The washings of the compact bone from patient 4 contained no detectable flucloxacillin. Filtration of the washings of hard trabecular bone of patient 10 through a $0 \cdot 2 \mu \mathrm{m}$ filter made no difference to the flucloxacillin concentration. Figure 2 shows the mean concentrations of flucloxacillin in sera and bone washings and the $95 \%$ upper and lower confidence limits of the means.

The marrow supernatants of patients 4 and 9 looked the same as serum, and contained 5.9 and $13 \mathrm{mg}$ flucloxacillin per $1,128.3$ and $76.5 \%$ of the corresponding serum concentrations. The marrow from patient 1 contained approximately 


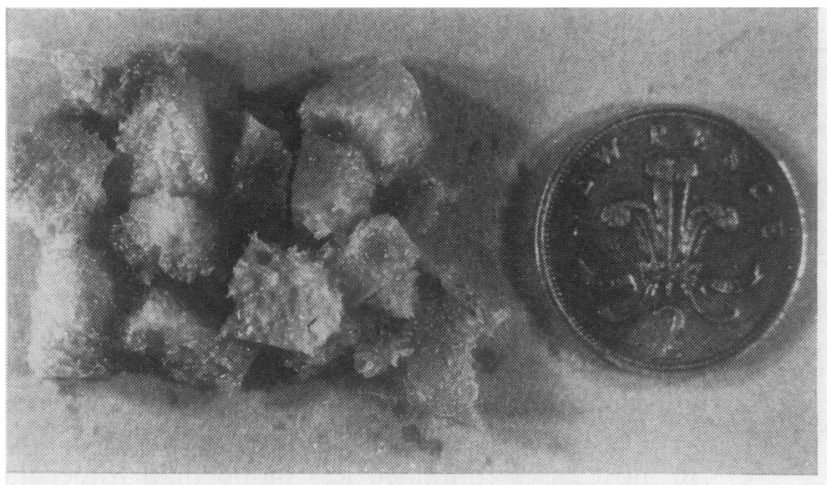

(a)

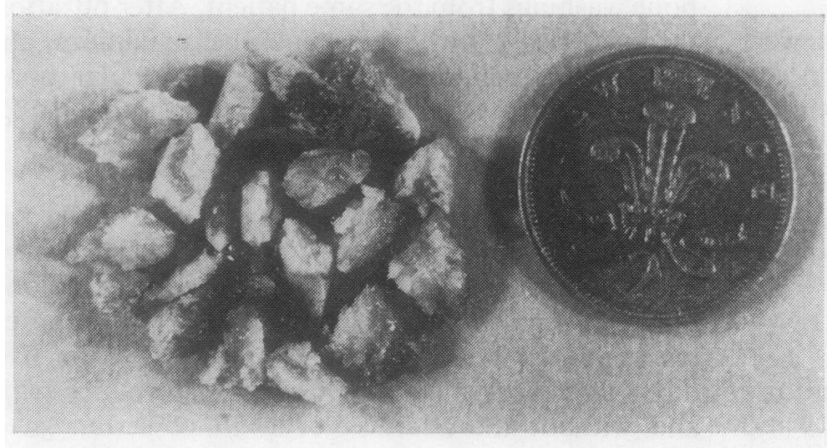

Fig. 1 (a) Trabecular bone pieces. 1 (b) Compact bone pieces. 1(c) Powdered bone: compact (left) and trabecular.

(b)

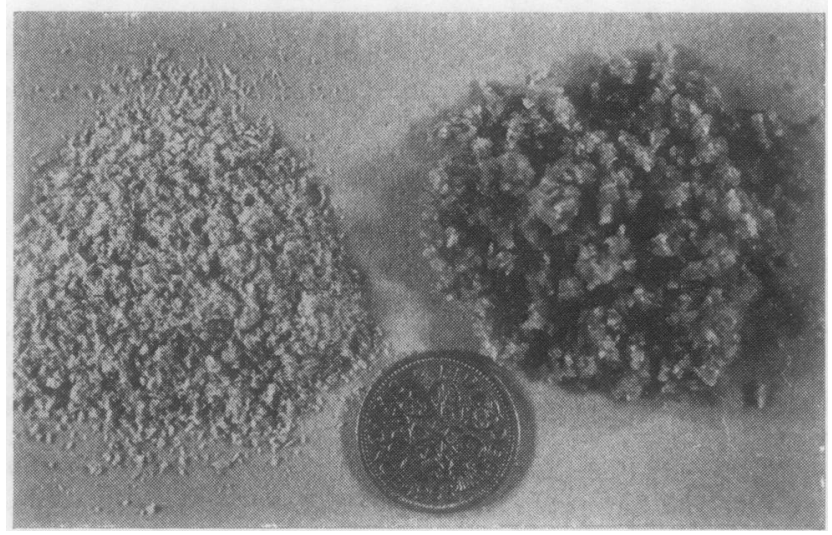

(c)

$50 \%$ cellular material, and assay of the whole aspirate showed the flucloxacillin concentration to be $2.5 \mathrm{mg} / 1,47.2 \%$ of the serum concentration. Marrow fat was aspirated from patient 10; it contained less than $0.8 \mathrm{mg}$ flucloxacillin per 1 . Packed erythrocytes of patient 7 contained flucloxacillin $0.4 \mathrm{mg} / \mathrm{l}$ and lysed erythrocytes $0.8 \mathrm{mg}$ flucloxacillin per $1,8.5$ and $17 \%$ of the serum level.

Serum concentrations were directly proportional to the weight-related doses of flucloxacillin. Trabecu- lar bone washings consistently had concentrations of flucloxacillin greater than or about the same as those in compact bone washings. Nineteen of 20 bone washings contained detectable flucloxacillin.

ANTIBIOTIC DUE TO CONTAMINATION Table 3 shows the blood haematocrits and the concentrations of flucloxacillin found in the sera andके bone washings of patients 1,9 , and 10 . From these data the concentration of flucloxacillin in the bone 
Table 2 Results of flucloxacillin assay of sera, bone washings, and marrow specimens

\begin{tabular}{|c|c|c|c|c|c|c|c|}
\hline \multirow[t]{4}{*}{ Patient } & \multirow{4}{*}{$\begin{array}{l}\text { Serum concentration } \\
\text { of flucloxacillin } \\
(\mathrm{mg} / \mathrm{l})\end{array}$} & \multicolumn{6}{|c|}{ Concentration ( $\mathrm{mg} / \mathrm{l}$ ) (and percentage of serum concentration) of fucloxacillin in: } \\
\hline & & \multicolumn{4}{|c|}{ Washings of } & \multirow{2}{*}{\multicolumn{2}{|c|}{$\begin{array}{l}\text { Marrow aspirate or supernatant } \\
\text { from marrow aspirate }\end{array}$}} \\
\hline & & \multicolumn{2}{|c|}{ Trabecular bone } & \multicolumn{2}{|c|}{ Compact bone } & & \\
\hline & & $m g / l$ & $\%$ & $m g / l$ & $\%$ & $m g / l$ & $\%$ \\
\hline 1 & $5 \cdot 3$ & 1.4 & $26 \cdot 4$ & $1 \cdot 2$ & $22 \cdot 6$ & $2 \cdot 5$ & $47 \cdot 2$ \\
\hline 2 & $5 \cdot 9$ & $1 \cdot 3$ & $22 \cdot 0$ & 0.7 & $11 \cdot 8$ & - & \\
\hline 3 & $12 \cdot 0$ & 1.6 & $13 \cdot 3$ & $1 \cdot 2$ & 10.0 & - & \\
\hline 4 & $4 \cdot 6$ & 1.0 & $21 \cdot 7$ & nd & - & $5 \cdot 9$ & $128 \cdot 3$ \\
\hline 5 & $7 \cdot 6$ & 0.9 & $11 \cdot 8$ & 0.4 & $5 \cdot 3$ & - & \\
\hline 6 & $7 \cdot 8$ & $1 \cdot 2$ & $15 \cdot 4$ & $1 \cdot 4$ & $17 \cdot 9$ & - & \\
\hline 7 & $4 \cdot 8$ & 0.3 & 6.3 & 0.3 & 6.3 & - & \\
\hline 8 & $10 \cdot 0$ & $2 \cdot 2$ & $22 \cdot 0$ & $2 \cdot 0$ & 20.0 & - & \\
\hline 9 & $17 \cdot 0$ & $2 \cdot 0$ & $11 \cdot 7$ & 0.9 & $5 \cdot 3$ & $13 \cdot 0$ & $76 \cdot 5$ \\
\hline 10 & $13 \cdot 5$ & 0.8 & 5.9 & 0.7 & $5 \cdot 2$ & nd & - \\
\hline
\end{tabular}

Table 3 Blood contamination of bone washings and contribution of contamination to total flucloxacillin in bone washings

\begin{tabular}{|c|c|c|c|c|c|c|c|c|c|c|}
\hline \multirow[t]{4}{*}{ Patient } & \multirow{4}{*}{$\begin{array}{l}\text { Nature } \\
\text { of bone }\end{array}$} & \multirow{4}{*}{$\begin{array}{l}\text { Maximum } \\
\text { absorbance } \\
\text { of bone } \\
\text { washings } \\
\text { (units) }\end{array}$} & \multicolumn{2}{|c|}{ Patient's venous blood } & \multirow{4}{*}{$\begin{array}{l}\text { Concentra- } \\
\text { tion of } \\
\text { blood }(v / v) \\
\text { in bone } \\
\text { washings } \\
(\%)\end{array}$} & \multicolumn{5}{|c|}{ Concentration of flucloxacillin in: } \\
\hline & & & \multirow{3}{*}{$\begin{array}{l}\text { Haemoglobin } \\
\text { concentration } \\
(\mathrm{g} / \mathrm{dl})\end{array}$} & \multirow{3}{*}{$\begin{array}{l}\text { Haematocrit } \\
(\%)\end{array}$} & & \multirow{3}{*}{$\begin{array}{l}\text { Patient's } \\
\text { serum } \\
(m g / l)\end{array}$} & \multicolumn{4}{|c|}{ Bone washings } \\
\hline & & & & & & & Total & Due $t$ & mination & Corrected \\
\hline & & & & & & & & $m g / l$ & $\%$ of total & \\
\hline 1 & $\mathbf{T}$ & $4 \cdot 7$ & $12 \cdot 0$ & 35 & 0.7 & $5 \cdot 3$ & 1.4 & 0.02 & $1 \cdot 7$ & $1 \cdot 38$ \\
\hline 1 & C & $2 \cdot 1$ & $12 \cdot 0$ & 35 & 0.3 & $5 \cdot 3$ & $1 \cdot 2$ & 0.01 & 0.8 & $1 \cdot 19$ \\
\hline 9 & $T$ & $11 \cdot 8$ & $13 \cdot 7$ & 45 & $2 \cdot 0$ & $17 \cdot 0$ & $2 \cdot 0$ & 0.2 & $9 \cdot 5$ & 1.9 \\
\hline 9 & C & 6.0 & $13 \cdot 7$ & 45 & 1.0 & $17 \cdot 0$ & 0.9 & 0.1 & 10 & 0.8 \\
\hline 10 & $\mathbf{T}(\mathbf{H})$ & $9 \cdot 2$ & 13.6 & 40 & 1.6 & $13 \cdot 5$ & 0.8 & $0 \cdot 1$ & 16 & 0.7 \\
\hline 10 & $T$ (S) & $15 \cdot 5$ & 13.6 & 40 & $2 \cdot 6$ & $13 \cdot 5$ & 0.8 & 0.2 & 26 & 0.6 \\
\hline 10 & C & $13 \cdot 2$ & 13.6 & 40 & $2 \cdot 2$ & $13 \cdot 5$ & 0.7 & 0.2 & 26 & 0.5 \\
\hline
\end{tabular}

$T=$ trahecular $;(H)=$ hard $;(S)=$ soft $; C=$ compact.

washings due to blood contamination was calculated. It ranged from 0.01 to $0.2 \mathrm{mg} / \mathrm{l}$, and the concentration was similar in washings of compact and trabecular bone from the same patient. Expressed as a percentage of total flucloxacillin in the washings, flucloxacillin due to blood contamination ranged from 0.8 to $26 \%$. The corrected concentrations of flucloxacillin in these washings range from 0.5 to $1.9 \mathrm{mg} / \mathrm{l}$.

\section{Discussion}

The results obtained were with uninfected osteoarthritic bone-and osteoarthritis is a common indication for total hip replacement. Little deterioration of flucloxacillin is likely to have taken place during storage of the bone, blood, or marrow samples before assay. Sutherland et al. (1970) showed that $10 \% \mathrm{w} / \mathrm{v}$ solutions of flucloxacillin are stable for 14 days at $5^{\circ} \mathrm{C}$. Our samples were exposed to room temperature only briefly.

Parsons (1976) discusses two methods of measur- ing the concentration of antibiotic in bone: that of grinding bone to a paste and then placing the paste in the well of an assay plate, and that of agitating $0.2 \mathrm{~g}$ particles of bone in buffer and then assaying antibiotic in the buffer. The method we used combines these elements. Bone particles, $1 \mu \mathrm{m}$ in diameter, can be produced by use of a bone mill (Hansen et al., 1975), but this may not be necessary to extract antibiotic, and heat production in the mill may be a disadvantage. The concentrations we found in bone washings may have tended to underestimate the concentration of flucloxacillin in the bone, which may have been higher by twofold or more, according to how complete was the extraction of flucloxacillin from bone and to the in vivo distribution of flucloxacillin between different sorts of bone tissue. The ease with which we extracted flucloxacillin from bone, and the higher concentrations in washings of trabecular than of compact bone, suggest that flucloxacillin may be present predominantly in the extracellular fluid of bone.

The assay was accurate to within $\pm 20 \%$; this 


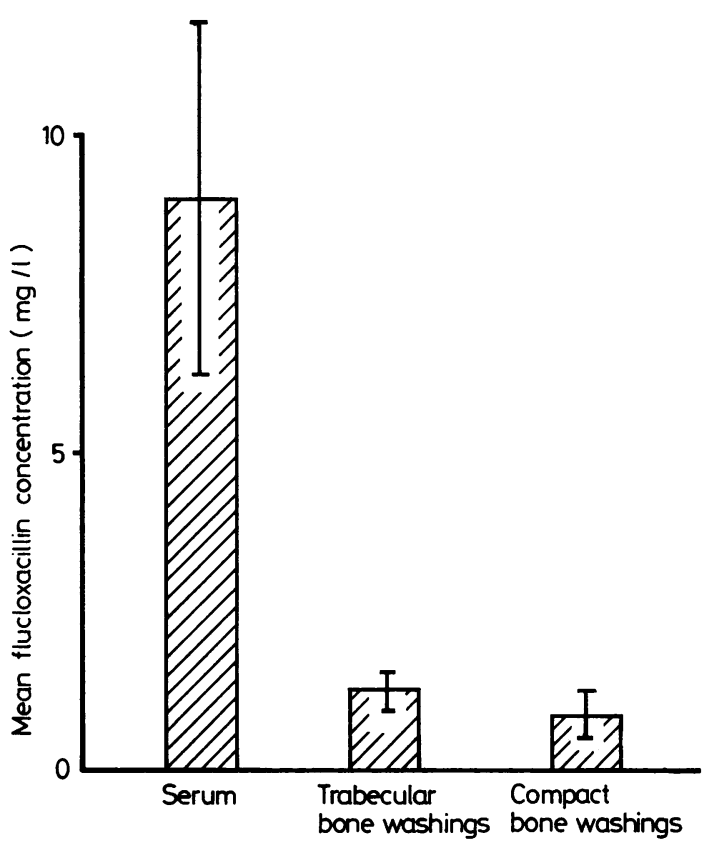

Fig. 2 Mean concentrations, and upper and lower $95 \%$ confidence limits of the means, of flucloxacillin in serum and washings of trabecular and compact bone.

compares favourably with the accuracy of plate assays of gentamicin in a series of clinical laboratories (Reeves, 1974). Fine growth occurred within zones of inhibition around wells containing only the lowest detectable concentrations of flucloxacillin. This phenomenon occurred equally with flucloxacillin standards and bone washings, so that assay was possible down to flucloxacillin levels in bone washings of $0.3 \mathrm{mg} / \mathrm{l}$.

Individual bones varied in vascularity, which may account for differences in haemoglobin concentration in washings. The concentrations of haemoglobin and of flucloxacillin in washings of one bone were little affected by filtration through a $0.2 \mu \mathrm{m}$ membrane. The haemoglobin in the control blood and in bone washings was treated in exactly the same way; in both cases most of it was probably converted to methaemoglobin. The wavelengths in the Soret band at which oxyhaemoglobin and methaemoglobin absorb maximally are 413 and $406 \mathrm{~nm}$ (Varley, 1967). Haemoglobin and these related compounds have similar molecular extinction coefficients in the Soret band (Lemberg and Legge, 1949). Hence dilutions of the control blood provided a valid means of measuring the blood contamination of the bone washings.

The formula used to calculate the amount of flucloxacillin in bone washings due to contamination with blood ignores any flucloxacillin contained in the erythrocytes. We found this to be little, and Kornguth and Kunin (1976) observed that erythrocytes incubated in serum for three hours took up only $13.5 \%$ of the original serum concentration of dicloxacillin. Also, the concentrations of flucloxacillin we found in marrow preparations were in roughly inverse proportion to the cellularity of the preparations. Thus, contamination with blood appears to account for at most $26 \%$ of the flucloxacillin in the bone washings, and often for considerably less.

The timing of the dose of flucloxacillin was intended to produce the maximum concentration of antibiotic in the blood and tissues at about the time when organisms might be introduced to the tissues at operation. The mean concentration of flucloxacillin in serum was $8.9 \mathrm{mg} / \mathrm{l}$. Trabecular bone washings had a mean flucloxacillin concentration of $1.3 \mathrm{mg} / \mathrm{l}$ and compact bone washings a mean concentration of $0.9 \mathrm{mg} / \mathrm{l}$. These represent respectively 15.6 and $11.6 \%$ of the corresponding serum concentrations. Work with penicillins related to flucloxacillin has given similar results: methicillin (Schurman et al., 1975) and oxacillin (Kolczun et al., 1974) were detected in bone at, respectively, $23 \%$ of a mean serum concentration of $11.6 \mathrm{mg} / \mathrm{l}$ (after a dose of $1 \mathrm{~g}$ intramuscularly) and $5-9 \%$ of a mean serum concentration of $86 \mathrm{mg} / \mathrm{l}$ (after a dose of $2 \mathrm{~g}$ intravenously).

Lacey and Stokes (1977) presented evidence that, with heavy inocula of growing organisms, flucloxacillin is susceptible in vitro to the penicillinase of Staph. aureus, and more so than cloxacillin. However, the significance of this is doubtful when these agents are used prophylactically in hip surgery, where small inocula of organisms in a resting state are likely.

The commonest organisms causing deep infection after total hip replacement are coagulase-positive and -negative staphylococci (Visuri et al., 1976). The minimum inhibitory concentrations of flucloxacillin for most strains of these organisms are in the range $0 \cdot 12-0.5 \mathrm{mg} / 1$ (Garrod et al., 1973b; Sutherland et al., 1970). The mean concentrations of flucloxacillin in trabecular and compact bone washings exceed these minimum inhibitory concentrations by about two- to 10-fold.

Methicillin resistance now occurs infrequently in Staph. aureus in Britain; less than $1 \%$ of consecutive isolates from septic lesions in seven London hospitals in 1973-75 were resistant (M. T. Parker, personal communication). It is a little more common among coagulase-negative staphylococci; a study of 820 strains of Staph. epidermidis (Baird-Parker groups. SII and SV), isolated from the skin of babies and 
adults in hospital, and of school children, showed $4.6 \%$ to be resistant to methicillin (J. F. Richardson, personal communication). Patients undergoing hipreplacement surgery have usually been recently admitted to hospital, and their skin flora may have changed little before the operation.

Only a small proportion of the cells of a methicillin-resistant strain of Staph. aureus capable of growing in the presence of high concentrations of methicillin at $30^{\circ} \mathrm{C}$ can do so at $37^{\circ} \mathrm{C}$ (Parker and Hewitt, 1970). Over two-thirds (26 of 38) of methicillin-resistant strains of Staph. epidermidis (SII) similarly showed only minimal resistance when tested at $37^{\circ} \mathrm{C}$ (J. F. Richardson, personal communication). Thus a small inoculum of a coagulasepositive or -negative staphylococcus into a wound is unlikely to contain cells capable of growing in the presence of methicillin in deep tissues.

The isoxazolyl penicillins have clinical advantages over various other antibiotics that have been studied in prophylaxis for hip-replacement surgery. It appears that flucloxacillin will reach concentrations in bone at the time of operation sufficient to inhibit the most likely pathogens causing deep postoperative infections, when given intramuscularly about two hours preoperatively, in a dose of $1 \mathrm{~g}$, or more, in persons of above average weight.

We thank Beechams Ltd for supplying flucloxacillin powder, Mr R. Sutherland for helpful discussions on assay and bone processing technique, and Drs G. C. E. McAll and N. J. Riddell for great help in obtaining specimens and patients' data.

\section{References}

Penson, M. K. D., and Hughes, S. P. F. (1975). Infection following total hip replacement in a general hospital without special orthopaedic facilities. Acta Orthopaedica Scandinavica, 46, 968-978.

Ericson, C., Lidgren, L., and Lindberg, L. (1973). Cloxacillin in the prophylaxis of postoperative infections of the hip. Journal of Bone and Joint Surgery, 55A, 808-813.
Garrod, L. P., Lambert, H. P., and O'Grady, F. (1973a). Fucidic acid. In Antibiotic and Chemotherapy, 4th edition, p. 201. Churchill Livingstone, Edinburgh and London.

Garrod, L. P., Lambert, H. P., and O'Grady, F. (1973b). Isoxazolyl penicillins. In Antiobiotic and Chemotherapy, 4th edition, pp. 74-76. Churchill Livingstone, Edinburgh and London.

Hansen, I., Nielsen, M. L. and Nielsen, J. B. (1975). A new method for homogenisation of bone exemplified by measurement of trimethoprim in human bone tissue. Acta Pharmacologica et Toxicologica, 37, 33-42.

Kolczun, M. C., Nelson, C. L., McHenry, M. C., Gavan, T. L., and Pinovich, P. (1974). Antibiotic concentrations in human bone. Journal of Bone and Joint Surgery, 56-A, 305-310.

Kornguth, M. L., and Kunin, C. M. (1976). Uptake of antibiotics by human erythrocytes. Journal of Infectious Diseases, 133, 175-184.

Lacey, R. W., and Stokes, A. (1977). Susceptibility of the 'penicillinase-resistant' penicillins and cephalosporins to penicillinase of Staphylococcus aureus. Journal of Clinical Pathology, 30, 35-39.

Lemberg, R., and Legge, J. W. (1949). Appendix: absorption spectra data. In their Hematin Compounds and Bile Pigments, pp. 748-749. Interscience, New York.

Parker, M. T., and Hewitt, J. H. (1970). Methicillin resistance in Staphylococcus aureus. Lancet, 1, 800-804.

Parsons, R. L. (1976). Leading article: antibiotics in bone. Journal of Antimicrobial Chemotherapy, 2, 228-231.

Reeves, D. S. (1974). Accuracy of gentamicin assays. Postgraduate Medical Journal, 50, supplement 20-23.

Schurman, D. J., Johnson, B. L., Jr., Finerman, G., and Amstutz, H. C. (1975). Antibiotic bone penetration: concentrations of methicillin and clindamycin phosphate in human bone taken during total hip replacement. Clinical Orthopaedics and Related Research, 111, 142-146.

Sutherland, R., Croydon, E. A. P., and Rolinson, G. N. (1970). Flucloxacillin, a new isoxazolyl penicillin, compared with oxacillin, cloxacillin and dicloxacillin. British Medical Journal, 4, 455-460.

Varley, H. (1967). Haemoglobin and related compounds. In his Practical Clinical Chemistry, 4th edition, p. 583. Heinemann, London.

Visuri, T., Antila, P., and Laurent, L. E. (1976). A comparison of dicloxacillin and ampicillin in the antibiotic prophylaxis of total hip replacement. Annales Chirurgiae et Gynaecologicae Fenniae, 65, 58-61. 